\title{
Legal Protection of Work Agreement Limited Duration between Employee and Contractor in Oil and Gas Company and the Ideal Roles of CSR Regarding to Positive Regulation in Indonesia
}

\author{
Nomensen Freddy Siahaan ${ }^{1}$, Ari Hernawan ${ }^{2}$ \\ \{nomensen.freddy1989@gmail.com ${ }^{1}$ \} \\ Student of Master of Legal Science Program, Gadjah Mada University, Yogyakarta, Indonesia ${ }^{1}$ \\ Lecture of Law Faculty of Gadjah Mada University, Yogyakarta, Indonesia ${ }^{2}$
}

\begin{abstract}
Legal Writing aims to answer the issues related to Manpower System especially toward Outsourcing Employee's Agreement in oil and gas company. The method which was used in this Scholar Paper was Qualitative Research Method, a kind of Normative Legal Writing which was based on prescriptive library research concerning study of positive law. For the Primary Legal Materials, Scholar used references such as Act Number 13 Year 2003 regarding to Manpower, Legal protections of working, etc. And for Secondary Legal Material, Scholar uses books, journals, papers, newspapers, and report of legal writing. Then, for Tertiary Legal Materials, Scholar used references such as legal dictionary, dictionary Indonesian-English dictionary and vice versa, etc. In the end of Legal Writing, Scholar concludes that: (1) there are some weaknesses that have found on Work Agreement Limited Duration. Those weaknesses have infringed Positive Regulation in Indonesia. (2) outsourcing Employees do not get totally preventive protection toward themselves because they could not access the right and for their families. Scholar recommends that the supervision from Governmental Officer has to be strengthened up to avoid many forms of infringements that would be happened in the next time.
\end{abstract}

Keywords: Work agreement, preventive protection, roles of CSR

\section{Introduction}

One of among the purposes of the establishment of Indonesia state government is to protect all of the people in Indonesia, respect toward the bloodshed of combatant, and achieve the general welfare, as mandated by Constitution of Republic of Indonesia of 1945. Therefore, Indonesia is obliged to provide protection for all citizens without exceptions. The essence of citizens protection is not only toward security, but also the legal protection of manpower in Indonesia (outsourcing and permanent manpower).

"Recently, the Company has focused on things to speed up operational processes, such as operations that require logistics to support acceleration, flexibility, price, and accuracy; A reliable information management system capable of presenting up-to-date data among divisions, production, warehousing, transportation, and customer service, as well as transactions that use 
less paper (electronic data transactions), interconnection among data, system analysis, and tracking systems. "[1]

Outsourcing is not about contract only, but more than of that, Maurice F. Greaver defined outsourcing as [2]: “Outsourcing is the act of transferring some of a company's recurring internal activities and decision rights to outside provider, as set forth in a contract. Because the activities are recurring on contract is used, outsourcing goes beyond the use of consultants. As a matter of practice, not only are the activities transferred, but also the factors of production and decision rights often are too. Factors of production are the resources that make the activities occur and include people, facilities, equipment, technology, and other assets. Decision rights are the responsibilities for making decisions over certain elements of the activities transferred"

Author has concluded toward outsourcing definition. Author argues that outsourcing can also be defined as transferring or delegating people or manpower from companies which are given to the goods and services provider institution toward operational services and administration management in order to maximize the productivity of companies, with the terms and condition as stipulated on agreement which has been agreed by all parties.

Outsourcing is a process to transfer liability or responsibility of manpower from holding or sub holding company to the other companies. The legality of the goods or service provider company could be acted as vendor or another institution which is depended on the agreement when it was established. Outsourcing System rules on Act Number 13 of 2003 regarding to Manpower, employees as supporting element (non-core business unit). More over in business system, there are some parties who has bound related to that regulation such as Government, Employer, and Employee.

But in fact, the capacities between them are unequal bargaining power. The employers usually have greatest bargaining power of them, followed by the Government, then the employees. But normally, the government should control and restrain the employers and employees. On business process, generally parties who are getting careless from our government are employees, because employees are used as a production factor only by employers who are not fully considered toward their welfare. It is seen when the employees are signing agreement, employees are faced by standard agreement which have been made by employers. Employees are given two opportunities only to decide, approving the contract or leaving the job offer. Outsourcing (Manpower Transferring) on Employment Law in Indonesia interpreted as chartering and the provision of employee services.

The legal arrangement related to outsourcing in Indonesia is regulated on Act Number 13 of 2003 regarding to Manpower (Article 64, 65 and 66) and

Decree of the Minister of Manpower and Transmigration of the Republic of Indonesia Number Kep.101/Men/VI/2004 of 2004 regarding to Procedures for Corporate Agreements of Employee Service Provider/Manpower and Decree of the Minister of Manpower and Transmigration of the Republic of Indonesia Number 220/Men/X/2004 regarding to terms of the levering as work implementation to the other companies.

Author argues that there's subject who will be concerned toward these problems and it is Corporate Social Responsibility (CSR). The implementation of CSR is not only the logical consequences of the absence of good corporate image in company but also play a role in improved performances and resources of companies are getting better than ever. CSR implementation could be realized in the social role of the company's internal environmental. In this case it would be well-being of its employees. The implementation of CSR is divided into internal (to the environment within the company) and external (to the public). Therefore, Author will present analyses related to outsourcing system, especially regarding to Working Agreement for Specified Period. 


\section{Issues}

To explore furthermore of the legal protection toward outsourcing system on Working Agreement for Specified Period, Author have some questions to be analyzed in this paper as follows:

- What is the critical or analyses toward Working Agreement for Limited Period?

- Has the Working Agreement for Limited Period given Preventive Protection toward Outsourcing Employees? And How is the role of Corporate Social Responsibility to protect the Employees' right?

\section{Methods}

This study uses Normative Legal Research. Normative Legal Research is a scientific procedure to find the truth based on the logic of the normative legal scientific. The scientific logic of normative Legal Research is developed by the scientific concentrate and ways of thinking of normative jurisprudence and their objects are regulation themselves. "Referring to Soerjono Soekanto's statement which states that legal writing is carried out by analyzing literature or secondary data which is called normative legal writing or literary law writing."[3]

On this writing study data is derived from secondary data. Secondary data is type of data that is not derived directly from the source, e.g. reading materials such as books, papers, or writing report, documents, regulations, jurisdiction, and other statistical data.

The legal materials, as objects of literature writing are divided into 3 (three) kinds of primary legal materials, secondary legal materials, tertiary legal materials. The legal materials of this writing are used:

a. Primary Legal Materials which the characteristic is bound by the writing, i.e.:

- Constitution of Republic of Indonesia of 1945;

- Civil Code;

- $\quad$ Act Number 13 of 2003 regarding to Manpower;

- Act Number 11 of 2005 regarding to the validity of International Covenant on Economic, Social, and Cultural Rights, Legal protections of work;

- Government Regulation of Indonesia Number 47 of 2012 regarding to Social and Environmental Responsibility of Company.

- etc

b. Secondary Legal Materials are the materials which explain about the primary legal materials such as books, journals, papers, newspapers, and report of legal research, and all varieties of written material on the internet website regarding to legal protection in Indonesia and the relationship toward positive regulation.

c. Tertiary Legal Materials is a material writing which provides references and explanations of the primary and secondary legal materials, such as legal dictionary, dictionary IndonesianEnglish dictionary and vice versa, etc.

On this writing, the tools which are used such as literatures or books (such as Strategic Outsourcing a Structured Approach to Outsourcing Decisions and Initiatives, American Management Association, USA which was composed by Maurice F. Greaver, Hukum Perburuhan di Indonesia which was composed by Abdul Rachmad Budiono, etc), regulations (such as Act Number 13 of 2003 regarding to Manpower, Decree of Minister of Manpower and Transmigration of the Republic of Indonesia Number PER-05/MEN/1995 regarding to Working 
Agreement for Specified Period in Oil and Gas company, etc), journals (such as M.G. Rood was acted as a presenter toward Employment Law Lectures at Padjajaran University Bandung, dated on August, 7th -9 th 1989, etc.

\section{Results and Analysis}

\subsection{The critical or analyses related to working agreement for limited period toward positive regulation}

On this chance, Author would like to show some analyses or critical toward the Agreement Limited Duration. These analyses or critical would give us understanding each bargaining position of the parties. Firstly Author would like to analyze related to Probation period. As stated on Act Number 13 of 2003 regarding to Manpower Article 58 Paragraph $1 \neg$ and 2 states that:

(1) Working agreements for specific period cannot require a probation period.

(2) In the case of the probation period being required in the working agreements as meant in paragraph 1 , the required probation period shall be null by law.

But in the other hand, as stated on Working Agreement for Specified Period, there is a probation period as long as 3 months (commencement date July, 18th 2011 up to October 31st 2011). It means that the Working Agreement for Specified Period was infringing the Act Number 13 of 2003 regarding to Manpower Article 58 Paragraph 1 and 2.

Then, Author would like to analyze regarding to categorization or characteristic of working. As stated on Act Number 13 of 2003 regarding to Manpower Article 59 Paragraph 1 and 2 states that:

4.1.1 Working agreements for a specific period only can be made for certain jobs which according to kind and characteristic or activities will be completed in a specified period, namely:

- Once completed or provisional jobs;

- Jobs expected to complete not too long and 3 (three) years at the maximum;

- Seasonal jobs; or

- Jobs related to new products, activities or additional products, which are still in trial run or exploration.

\subsubsection{Working agreements for a specified period cannot be applied to regular jobs}

A job may be regarded as temporary if it is understood by both of them that the termination of the job is determined by objective conditions such as reaching a certain date, completion of an assignment or return of another employee who has been temporarily replaced [12]. In the case of a work contract of limited duration the condition for its termination is generally mentioned in the contract. To be included in these groups are:

a. People with a seasonal job,

b. People who is engaged by an employment agency or business and hired out to a third party for the carrying out of a "work mission" (unless there is a work contract of unlimited duration with the employment agency or business),

c. People with specific training contracts. 
But according to Working Agreement for Specified Period, Author was placed as Outsourcing Legal Officer which would be focus on making contract (coordination among divisions), include of analyzing the tender steps. This job would be continuously needed because without Legal Officer, company's operational would not be protected by law and will be disturbed. Legal Officer is one of core subjects which completely important to advise company in order to avoid the Law infringement so that the operational of company would be run well. Morover oil and gas industry which is sensitive because it dominates the life of many people. So that, it is not properly if Legal Officer was placed as outsourcing employee. Because that position is one of strategic position to run the operation of company.

On this chance, Author also would like to analyze furthermore regarding to working hours. According to Act Number 13 of 2003 regarding to Manpower Article 77 Paragraph 2 states that the working hour as meant in paragraph 1 shall include:

a. 7 (seven) hours on one day and 40 (forty) hours on one week in the case of the working period being 6 (six) days on one week;

b. 8 (eight) hours on one day and 40 (forty) hours on one week in the case of the working periods being 5 (five) days on one week.

It is accordance with Working Agreement for Specified Period on Article 3

a. Monday - Thursday $=07.30-12.30$ and $14.30-17.30$

b. Friday $\quad=07.30-11.30$ and 13.30-17.30

But the implementation may be is not suitable with Work Agreement. As we know together, Oil and Gas Company has a systematic operational. It means the operational of working hours of each employees might be hectic and excessive of working hours as stated on Working Agreement for Specified Period. Employee might arrive in the office at 07.00 a.m. and used their breaking hours for working, and were going home around 07.00-08.00 p.m. As stated on Working Agreement for Specified Period, Employee did not get any extra bonus toward overtime of working because the salary system was all in. All of the transportations, consumption, over time budget, etc has been included in salary. And it is possible to head officer suggested Employee to come in the weekend for working again. It means that employee would not get the weekend if it is implemented.

According to Author's conclusion, overtime could be given for emergency condition only. It could be held if overtime is absolutely needed to support company's operational. But when Author was working at Oil and Gas Company, Employees might have overtime to accomplish their duties which was given to them. Whereas it was not categorized as emergency duties.

Furthermore, Author would like to analyze related to Work Training. Author find on Act Number 13 of 2003 regarding to Manpower Article 9 states that "Vocational training shall be organized and directed to provide, enhance and develop work competence for driving up capability, productivity and welfare."

But in fact of this regulation is not in accordance with the Working Agreement for Specified Period. On probation test, Employees did not get special training as a preparation to develop and improve employee's capability. Employees directly worked at Oil and Gas Company after approving in that company as Employees' job descriptions and directly supervised by head of department.

Next, Author would like to analyze regarding to all-in system salary. According to it, it is not specific regulated by positive regulation in Indonesia. There some doctrines which was stated that all-in system is implemented to make simply documentation (we do not have to make overtime documents, extra bonus documents, etc) because company has estimated load factor of employees which wouldn't be added or decreased. 
Like Author said before, overtime might be happened for every employee when they were working. As we know together that Oil and Gas Company has a systematic operational and it is effected to industry operational. Every employee might get so many tasks that they had to accomplish as soon as possible (was limited by deadline), but they did not get extra bonus although they had overtime working (as stated on Working Agreement Limited Duration, the working system was all-in salary system). Therefore, it is not accordance with Act Number 13 of 2003 regarding to Manpower Article 78 Paragraph 2.

If the situations like these, employee could not access their right to enhance their welfare life, moreover their families. Besides there is not provided extra bonus for overtime working, it is not also stated related to facilities would be given to the employee's family like their spouse (wife or husband), child or children, etc. And it is not also stated on Working Agreement for Specified Period related to covering of insurance for family members like wife, child or children.

\subsection{Preventive protection and ideal roles of corporate social responsibility to handle the outsourcing employees}

After explanation above, Author would like conclude that Working Agreement for Specified Period does not completely fulfill Preventive Legal Protection as stated on Act Number 11 of 2005 regarding to the validity of International Covenant on Economic, Social, and Cultural Rights, especially toward Technical and Economical Protection. Author says like that because there are so many unsynchronized Working Agreement for Specified Period toward that regulation.

Like Act Number 11 of 2005 regarding to the validity of International Covenant on Economic, Social, and Cultural Rights Article 7 alphabet b about Technical Protection which is written every country that has ratified the covenant has to confess everyone's right to enjoy equitable and fairness of working.

Although Author thought that equitable and fairness could not be accessed because Author was placed as Outsourcing Legal Officer which would be focus on making contract (coordination among divisions), include of analyzing the tender steps. This job would be continuously needed because without Legal Officer, company's operational would not be protected by law and will be disturbed. Legal Officer is one of core subjects which completely important to advise company in order to avoid the Law infringement so that the operational of company would be run well. More over Oil and Gas Company has a systematic operational which is sensitive because it dominates the life of many people. So that, it is not properly if Legal Officer was placed as outsourcing employee but placed as permanent employee.

Besides that, Author feels that Working Agreement for Specified Period is not equitable and fair enough because that contract has standardized by company. The forming of agreement was made by one party only (company). Employees could negotiate salary and supporting facilities only. The whole of substances of agreement has been made in standard contract. Employees get two choices only. "take it or leave it". Therefore it is infringe the Civil Code Article 1320 and Act Number 13 of 2003 regarding to Manpower Article 52 Paragraph 1 regarding to the consensus of both of parties.

Then Author would like to analyze another perspective of preventive legal protection toward the working system. Author still believes that the working system does not fulfill Preventive Legal Protection because the supervision of government institution like Manpower and Transmigration Government Officer is still weak. It was proved by there are so many infringements that was found on Working Agreement for Specified Period (like Author has 
stated above). This Working Agreement for Specified Period is not accordance with Positive Regulation in Indonesia especially Act Number 13 of 2003 regarding to Manpower Article.

If the supervision of Manpower and Transmigration Government Institution is proper enough, Author believe that Government Officer will take decisive action by giving the warning to user company or punishment (if it is possible). It is depended to the categorization of infringement that has been done by user company.

After talking about Preventive Protection, Author would like to explain about Corporate Social Responsibility. As we know together, Corporate Social Responsibility has two main roles in company such internal role and external role. For internal role, Corporate Social Responsibility has duty to enhance and care about the welfare of employees, include of the salary, extra bonus when having overtime. And for external role, Corporate Social Responsibility obliges to care toward the social environmental around that company such as build a mosque, church, bridge, etc. But right now, Author want to talk about internal role of Corporate Social Responsibility only.

Corporate Social Responsibility is the continuing commitment by business to behave ethically and contribute to economic development while improving the quality of work life of the workforce's employees and their families as well as of the local community and society at large. [4] Corporate Social Responsibility centers on the relationship between business and society and how businesses behave towards their key stakeholders such as employees, customers, investors, suppliers, communities, and special interest groups. It describes what new Corporate Social Responsibility agenda as follows: It identifies a new and enlarged responsibility for businesses today in contributing to both the well-being of society in general and the integrity of the natural environment.

But, Author thought that Corporate Social Responsibility in Oil and Gas Company does not fulfill the economy responsibility because does not care toward the welfare of outsourcing employees. Outsourcing employees who have overtime working do not get more money. Because the salary system is all in system. Everything that Employees will do, they will get same nominal of salary in every month.

Author is reminded by the statement of Janet Blake[5] who is stated that:

"We know, because we have the evidence, that employees who are proud of the CSR achievements [of BT] and feel involved in those CSR achievements and see that it mirrors their own personal responsibility are more motivated, more effective and they're more feeling like driving the business further, more productive and motivated as a workforce. I think secondarily, employees take a very important message out to our customers, because if they are motivated and understand what a good responsible business looks like, they will embed it into how they do their job, and that means that they will be seeking about CSR as they make decisions about customers and that in turn brings a better benefit to our customers."

So that if the reality like this, Outsourcing employees who have all-in salary system, feel that Corporate Social Responsibility in Oil and Gas Company is failed because could not drive the business further, more productive, and motivated all of employees as a workforce. It might be the Outsourcing employees who have done all of their obligation and taken overtime to accomplish their duties, would not be motivated and productive again because they do not get extra salary toward their overtime working.

After explanation above, Author concludes that Corporate Social Responsibility at Oil and Gas Company does not fulfill the ideal roles to enhance the welfare of Outsourcing Employees and care about the welfare and rights of them. It is proved when Outsourcing Employees who 
have overtime working, they do not get more money as extra bonus and does not give training to new Outsourcing Employees who would be worked in that company.

\section{Conclusion and Recommendation}

\subsection{Conclusion}

After explanation above, in the end Author would like to conclude some points related to the contents, such as there are some weaknesses that have found on Working Agreement for Limited Period. Those weaknesses have infringed Positive Regulation in Indonesia, such as the position of Legal Officer as Outsourcing Employee, does not provide training program, etc.

Outsourcing Employees do not get totally preventive protection toward themselves because they could not access the right and for their families, supervision from governmental officer is still weakness, and the protection is not given by Corporate Social Responsibility in that company. It is proved that Corporate Social does not also fulfill the internal roles to enhance the welfare of Outsourcing Employees and care toward rights of them.

\subsection{Recommendation}

From the issues above, Author would like to give some recommendation as solution, such as:

- The substantial of Working Agreement for Specified Period should be formulated again especially toward the protection of Outsourcing Employee's rights which need to be covered up. The outsourcing employee must has the equal bargaining position to discuss the contents of Working Agreement for Specified Period.

- The supervision from Governmental Officer has to be strengthened up to avoid many forms of infringements that would be happened in the next time. Because it is absolutely needed as a mediator to control employer's position who sometimes does arbitrary actions toward the employees.

\section{References}

[1] R. Eko and R. Djokopran, Proses Bisnis Outsourcing. Grasindo, 2006.

[2] M. F. Greaver and M. F. Greaver II, Strategic outsourcing: a structured approach to outsourcing decisions and initiatives. Amacom books, 1999.

[3] S. Soekanto and S. Mamudji, Penelitian hukum normatif: Suatu tinjauan singkat. RajaGrafindo Persada, 2001.

[4] S. Hick, "Morals maketh the money," Aust. CPA, vol. 70, no. 4, p. 72, 2000.

[5] J. Blake, "From protection to innovation: BT's journey in corporate social responsibility," Glob. Bus. Organ. Excell., vol. 26, no. 1, pp. 7-17, 2006

[6] Constitution of Republic of Indonesia of 1945.

[7] Act Number 13 of 2003 regarding to Manpower.

[8] President Instruction Number 3 of 2006 regarding to Investment Climate Policy Packaging.

[9] Decree of Minister of Manpower and Transmigration of the Republic of Indonesia Number PER05/MEN/1995 regarding to Working Agreement for Specified Period in Oil and Gas company. 
[10] Decree of the Minister of Manpower and Transmigration of the Republic of Indonesia Number Kep.101/Men/VI/2004 of 2004 regarding to Procedures for Corporate Agreements of Employee Service Provider/Manpower.

[11] Decree of the Minister of Manpower and Transmigration of the Republic of Indonesia Number 220/Men/X/2004 regarding to terms of the levering as work implementation to the other companies.

[12] Noviasari, D. T., \& Nurwati, N. (2020). Perlindungan Tenaga Kerja Disabilitas dalam Perspektif Hak Asasi Manusia. Borobudur Law Review, 2(1), 16-29. 